\title{
Geo-environmental zoning using physiographic compartmentalization: a proposal for supporting sustainable decision-making
}

\author{
CLAUDIA V.S. CORRÊA ${ }^{1}$, FÁBIO A.G.V. REIS ${ }^{1}$, LUCILIA C. GIORDANO ${ }^{1}$, ADRIANO BRESSANE ${ }^{2}$, CAMILA \\ J. CHAVES ${ }^{1}$, ANA MARIA C. DO AMARAL ${ }^{1}$, HERMES D. BRITO ${ }^{1}$ and GERSON A. DE MEDEIROS ${ }^{2}$ \\ ${ }^{1}$ Pós-Graduação em Geociências e Meio Ambiente, Universidade Estadual Paulista, \\ Avenida 24A, 1515, Bela Vista, 13506-900 Rio Claro, SP, Brazil \\ ${ }^{2}$ Pós-Graduação em Ciências Ambientais, Universidade Estadual Paulista, Avenida \\ Três de Março, 511, Aparecidinha, 18087-180 Sorocaba, SP, Brazil
}

Manuscript received on December 18, 2016; accepted for publication on May 3, 2017

\begin{abstract}
The geo-environmental zoning represents an important strategy in the territorial management. However, it requires a logical and structured procedure. Therefore, an approach using physiographic compartmentalization is proposed and applied as case study in a region covered by the topographic maps of São José dos Campos and Jacareí, Brazil. This region has great geological and geomorphological peculiarities, beyond being a place with large human interventions because of its quickly economic growth. The methodology is based on photointerpretation techniques and remote sensing in GIS environment. As a result, seven geo-environmental zones were obtained from a weighted integration by multicriteria analysis of physiographic units with land-use classes. In conclusion, taking into account potentialities and limitations, the proposed approach can be considered able to support sustainable decision-making, being applicable in other regions.
\end{abstract}

Key words: remote sensing, decision-support, earth sciences, land use.

\section{INTRODUCTION}

Human activities on the Earth's surface are directly related to the physical environment, increasing the occurrence of geodynamic processes, such as landslides, siltation, flooding, and others (Corrêa 2013). Therefore, the lack of knowledge regarding the physical environment represents an aggravating factor, once it is essential to formulate and implement successful strategies in the

Correspondence to: Fábio Augusto Gomes Vieira Reis

E-mail: fabioreis@rc.unesp.br environmental management (Fernandes-da-Silva et al. 2010).

For that, geographical information systems (GIS) provide a powerful tool for geo-environmental evaluation in support of land-use planning. Thus, several approaches of geo-environmental fragility/ vulnerability evaluation that used GIS and remote sensing were developed over the last few years (e.g. Szlafsztein and Sterr 2007, Pandey et al. 2008, Anfuso and Del Pozo 2009, Andrade et al. 2010, Fernandes-da-Silva et al. 2010, Ifeanyi et al. 2010, Fernández and Lutz 2010, Pourebrahim 
et al. 2011, Bathrellos et al. 2012, Manfré et al. 2013). All these works highlighted the ability of the GIS to integrate multiple layers of information and the great potential of GIS-based environmental evaluation for management.

The integration of multiple layers can be realized using multicriteria analysis (MCA), which are well-known decision-support tools for dealing with complex issues where technological, economical, ecological and social aspects have to be covered to optimize land use planning. Hence, these techniques have been repeatedly combined with GIS to provide a powerful visual decisionsupport for rational land use mapping (Tudes and Yigiter 2010).

From the foregoing, this paper aims to analyze the use of a multicriteria method based on the integration of physiographic and land use units to produce a geo-environmental mapping of the region covered by the topographic maps of São José dos Campos and Jacaré́, São Paulo State, Brazil. This area is characterized by several fragile geo-ecosystems and by the intense intervention of anthropic activities. For that, the proposal includes physiographic analysis as a key step for the geoenvironmental mapping, following the propositions of Fernandes-da-Silva et al. (2010).

\section{STUDY AREA}

The study area is located in the Middle Paraíba do Sul Valley, São Paulo State, in the region covered by the topographic maps (scale 1:50,000) of São José dos Campos (SF-23-YD-II-1) (IBGE 1973) and Jacarei (SF-23-YD-II-3) (IBGE 1974), limited by the parallels $23^{\circ} 00^{\prime} \mathrm{S}$ and $23^{\circ} 30^{\prime} \mathrm{S}$, and meridians $46^{\circ} 00^{\prime} \mathrm{W}$ and $45^{\circ} 45^{\prime} \mathrm{W}$ (Figure 1).

In addition, we chose the study area due to the occurrence of several landscape units with different geological and geomorphological characteristics for application of the methodology, ranging from mountain escarpment areas in the Crystalline Basin to stretches of the alluvial plains of the Paraíba do Sul river, inserted in the Sedimentary Basin of Taubaté.

In general, according to the Köppen classification, the climate permeates between the CFA, oceanic subtropical, and Aw, seasonal tropical with a dry season in winter (Kottek et al. 2006). In terms of the geological context, the Paraíba Valley falls within the sedimentary Taubaté Basin and it is limited by the crystalline basement of Serra do Mar and the Mantiqueira mountain range, which consists mainly of gneiss and granite sequences. The sedimentary Taubaté Basin consists of sediments from the Tertiary, which are represented by the Resende, Tremembé, São Paulo, and Pindamonhangaba Formations, and Quaternary Periods (Figure 2).

The area is part of the Atlantic Plateau Province in the Middle Paraíba do Sul Valley zone according to the geomorphological division of São Paulo State (IPT 1981). The Middle Paraíba do Sul Valley is divided into a region of hills that developed on Precambrian crystalline rocks, which are known as the Crystalline Hills, and in a region called Sedimentary Hills, which is located in the sedimentary Taubaté Basin and flood plain; the Quaternary sediments in this region originated from the neo-morphodynamics of the Paraíba do Sul River (Figure 3).

\section{MATERIALS AND METHODS}

The technique used in this study consisted of available physical and anthropogenic attributes to construct a geo-environmental map. Three main steps were performed: physiographic compartmentalization, land-use mapping and geoenvironmental mapping. These steps were based on the concept of Aswathanarayana (1995), in which the term "geo-environmental" refers to portions of the Earth affected by human activities, composed by rocks, soils, fluids, gases and organisms. In this 

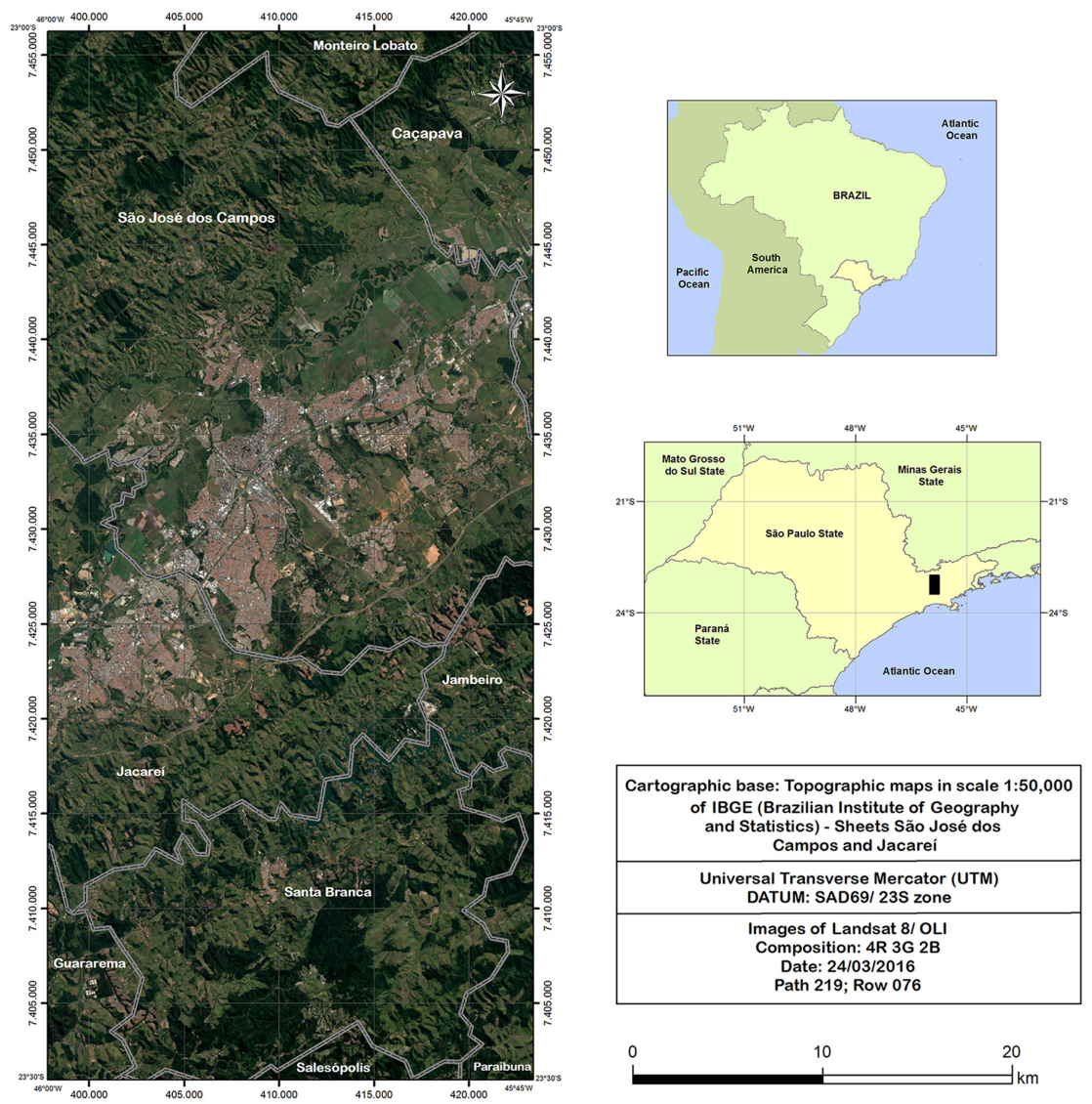

Figure 1 - Location of study area.

context, Jimenez-Rueda et al. (1995) defined geoenvironmental zoning as a systematic analysis tool through the survey of many physical environmental variables, such as lithology, physiographics and land-use units. According to the same authors, the analysis of these variables presents the potentiality and support capacity of the physical environment, based on the natural constraints and socioeconomic modifiers.

Cartographic aspects were adopted as the coordinate system for the produced maps; both steps used the UTM (Universal Transverse Mercator) Plane Coordinate System, Datum SAD69 (South America-1969) - Zone 23S, 1:100,000 scale.
PHYSIOGRAPHIC COMPARTMENTALIZATION

Oliveira (2004) used the physiographic compartmentalization method to group the elements of the physical environment according to their similarities and differences. When an element can be grouped, it should be determined first to ascertain whether this element has common characteristics to those of the analyzed universe. Thus, the foreclosure process must be preceded by a classification process in which the elements that have the same characteristics, or are closer to each other, are grouped.

The method used for the physiographic compartmentalization is an integrated physiographic analysis (Fernandes-da-Silva et al. 


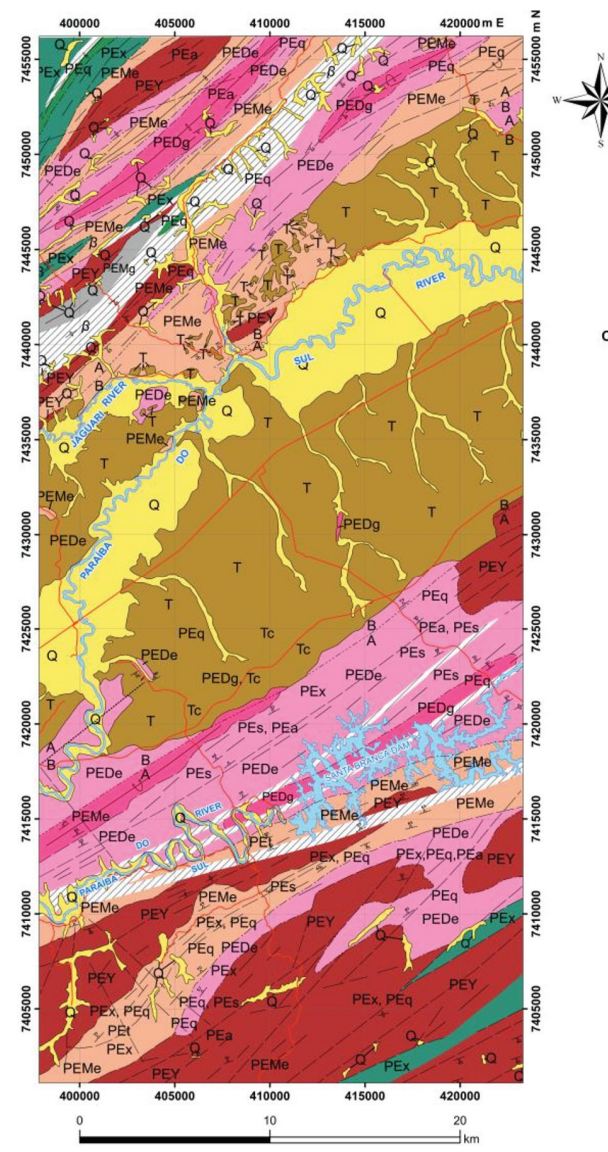

Figure 2 - Geological context in the study area.

2010). According to Vedovello (2000) and Zaine (2011), this type of analysis includes an analyticalsynthetic approach that is derived from terrestrial systems, and which uses the physiognomy of land, or landscape patterns, as reference standards.

The physiographic compartmentalization was performed by means of an analysis of the elements in the physical environment, which may be of geological or geomorphological nature, and by identifying the local aspects of these elements, i.e., their forms of occurrence (Vedovello and Mattos 1993, 1998). Several studies have corroborated this assertion, stressing that compartmentalization should mainly use the textural properties of the analyzed environment as a reference (Zaine 2011, Silva et al. 2010, Cardoso et al. 2009, Côrrea et al. 2014, Pilachevsky et al. 2015, Amaral et al. 2015).
Legend
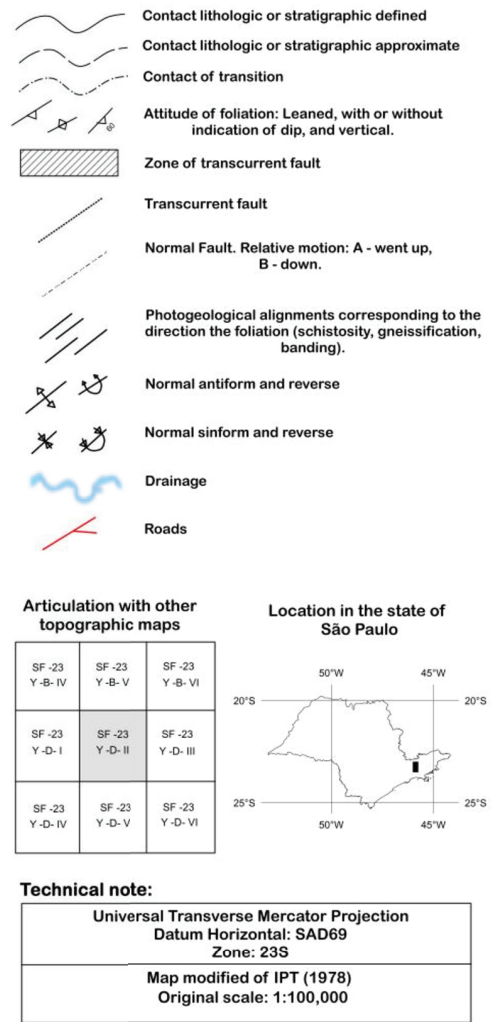

The study of Zaine (2011), on textures, shapes and structures, follows the steps of photoreading, photoanalysis and photointerpretation. According to Soares and Fiori (1976), photoreading corresponds to the recognition of texture elements of interest in an image. Photoanalysis involves the association and ordering of parts of an image, and photointerpretation analyses aim to discover and evaluate the meaning, function and relationship of objects in the images by inductive, deductive and comparative methods.

The photoreading was based on the identification of techniques and collection of orbital images, such as spatial resolution, spectral resolution and the solar angle, beyond the recognition of texture elements of interest in an image (Soares and Fiori 1976). The methodology 


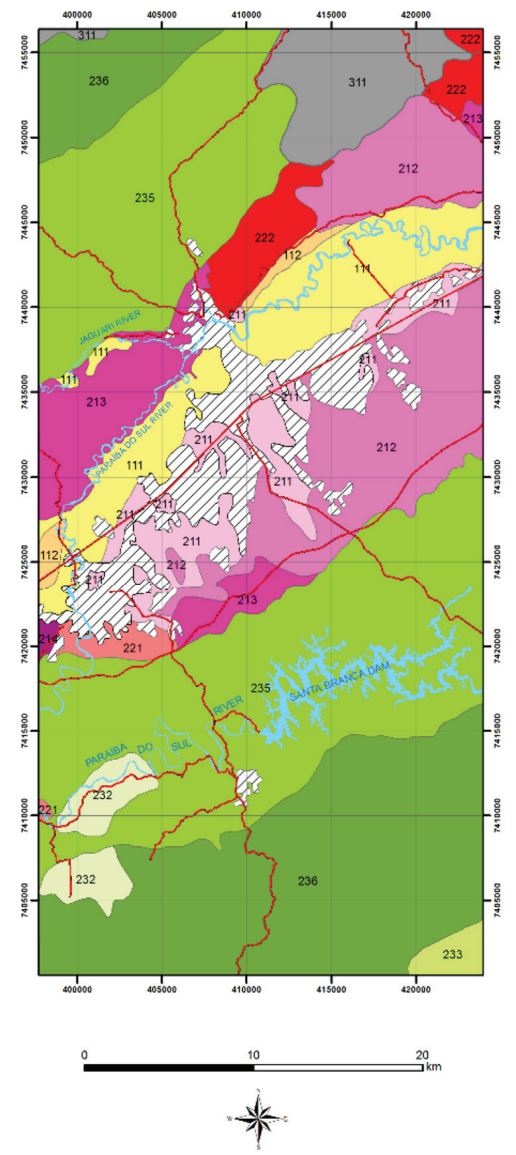

Figure 3 - Geomorphological division in the study area.

established by these authors, based on the logical method of interpretation of remote sensing images, is widely used by other authors, such as Diniz et al. (2016), Manfré et al. (2013) and Tinós et al. (2014).

Among the materials used are topographic maps $(1: 50,000)$ provided by the IBGE (Instituto Brasileiro de Geografia e Estatística), a geological map $(1: 100,000)$ from the IPT (Instituto de Pesquisas Tecnológicas do Estado de São Paulo), a geomorphological map of Paraíba do Sul Valley (1:250,000) (Florenzano and Csordas 1993), and Landsat-5 images from band 4, which were dated to $08 / 19 / 87$, and bands 3,4 and 5, which were dated to $04 / 21 / 2011$ with path 219 and row 76. The use of 1987 images to perform the physiographic compartmentalization is due to the degree of lower anthropic interference, because as the study area is very urbanized, relief forms may be currently masked. Therefore, older remote sensing images enable a more accurate analysis of the relief elements of the region. The geological and geomorphological maps were used to help field surveys and support the photointerpretation analysis, during the physiographic compartmentalization. The morphometric data, which are represented by slope and hypsometric maps, were prepared from the data obtained by the TOPODATA system (INPE 2008), generated by the digital processing of the DEM (Digital Elevation Model) of the SRTM (Shuttle Radar Topographic Mission).

The use of band 4 was important because this operates in the wavelength that corresponds to $0.76-0.90$ micrometers (near-infrared), which is sensitive to morphology of of the terrain 
(Florenzano 2008, Anbazaghan et al. 2011). Thus, Lima et al. (2013) and Cardoso et al. (2009) also chose this band to analyze the geomorphological and geological aspects in their study areas. For the next steps, the same image experienced two digital processing steps in the SPRING software: linear contrasting and linear filtering enhancement (Laplaciano). Linear contrasting aims to expand the digital image range for the total dynamic range (0-255) to increase the visual contrast of the image. Linear filtering enhancement (Laplaciano) contrasts the high frequency components, favoring the differentiation of the textural aspects of the image.

The photoanalysis corresponded to the division of the area in terms of its geological aspects, considering the different lithologies found in the study area, mainly by differentiating sedimentary and crystalline rocks. Then, analyses of the shape, texture, and structure of relief elements were considered as reference for the delimitation of the different compartments from the hypsometric, slope and hydrographic maps. This step followed the propositions of the analysis performed by Zaine (2011) (Table I). This method aimed to obtain a geological-geotechnical map that is sectioned in various terrain units, and which includes characteristics related to the relief, geology and land use, in which the information is summed and presented by an integrated analysis according to the logic method by Soares and Fiori (1976). The chart by Zaine (2011) considers the analysis of textural density (corresponding to the elements of drainage and relief), shape and relief characteristics, geological structures (structural elements) and the complementary data (land use and geological processes in the area).

Finally, the photointerpretation step was based on an assimilation of the photoanalysis results, identifying the meaning of the shapes and characteristics of the delimited units, in the context of its function in the environment (Fernandes-daSilva et al. 2010).

In terms of the geological-geotechnical characterization, the framework proposed by Zaine (2011) combines the results of the previous steps with data from the field survey. In this study, the geological-geotechnical characterization was conducted based on the textural properties and spectral analysis of the images. According to Vedovello (2000), the principle for this analysis is that the texture features in the images reflect the material properties and characteristics of the investigated target. Thus, the analysis performed in this step followed the guidelines of the "Applications", "Analysis of textural density", and "Analysis of forms and relief characteristics" proposed by Zaine (2011).

\section{LAND-USE MAPPING}

Obtaining detailed and accurate information regarding the geographic space is a necessary condition for planning activities and decisionmaking. Land-use cover maps are tools that help to conduct this purpose, consist of mechanisms able to promote suitable development, and are indispensable to the regional or local planning of terrain.

For this step, Landsat-5 images (bands 3, 4 and 5, which were dated to $04 / 21 / 2011$ with path 219 and row 76) were subjected to linear contrasting in the SPRING software (INPE 2011), which allows a greater spreading of the pixels in each orbital image. In the same software, the colored composition 3B4G5R (false color) was included to execute the segmentation and supervised classification processes. The selected operation for the segmentation was region-growing, which consists in a data clustering considering the similarities with adjacent regions. After segmentation, a supervised classification was performed by using the Bhattacharya algorithm, whose acceptance 
TABLE I

Chart of photoanalysis and photointerpretation according Zaine (2011).

\begin{tabular}{|c|c|c|c|c|}
\hline Analysis of textural density & \multicolumn{4}{|c|}{ Classes } \\
\hline Elements of analysis & \multicolumn{4}{|c|}{ Elements of drainage and relief } \\
\hline \multirow{3}{*}{ Analysis criteria } & Density of drainage & Low & Medium & High \\
\hline & elements & 0 to $5 / 10 \mathrm{~km}^{2}$ & 5 to $30 / 10 \mathrm{~km}^{2}$ & $>30 \mathrm{~km}^{2}$ \\
\hline & $\begin{array}{c}\text { Density of elements } \\
\text { relief }\end{array}$ & Low & Medium & High \\
\hline Property to be interpreted & $\begin{array}{l}\text { Permeability } \\
\text { (intergranular) }\end{array}$ & High & Medium & Low \\
\hline Aplications & $\begin{array}{l}\text { Relationship runoff/ } \\
\text { infiltration }\end{array}$ & Low & Medium & High \\
\hline
\end{tabular}

Analysis of forms and relief characteristics

Classes

Elements of analysis

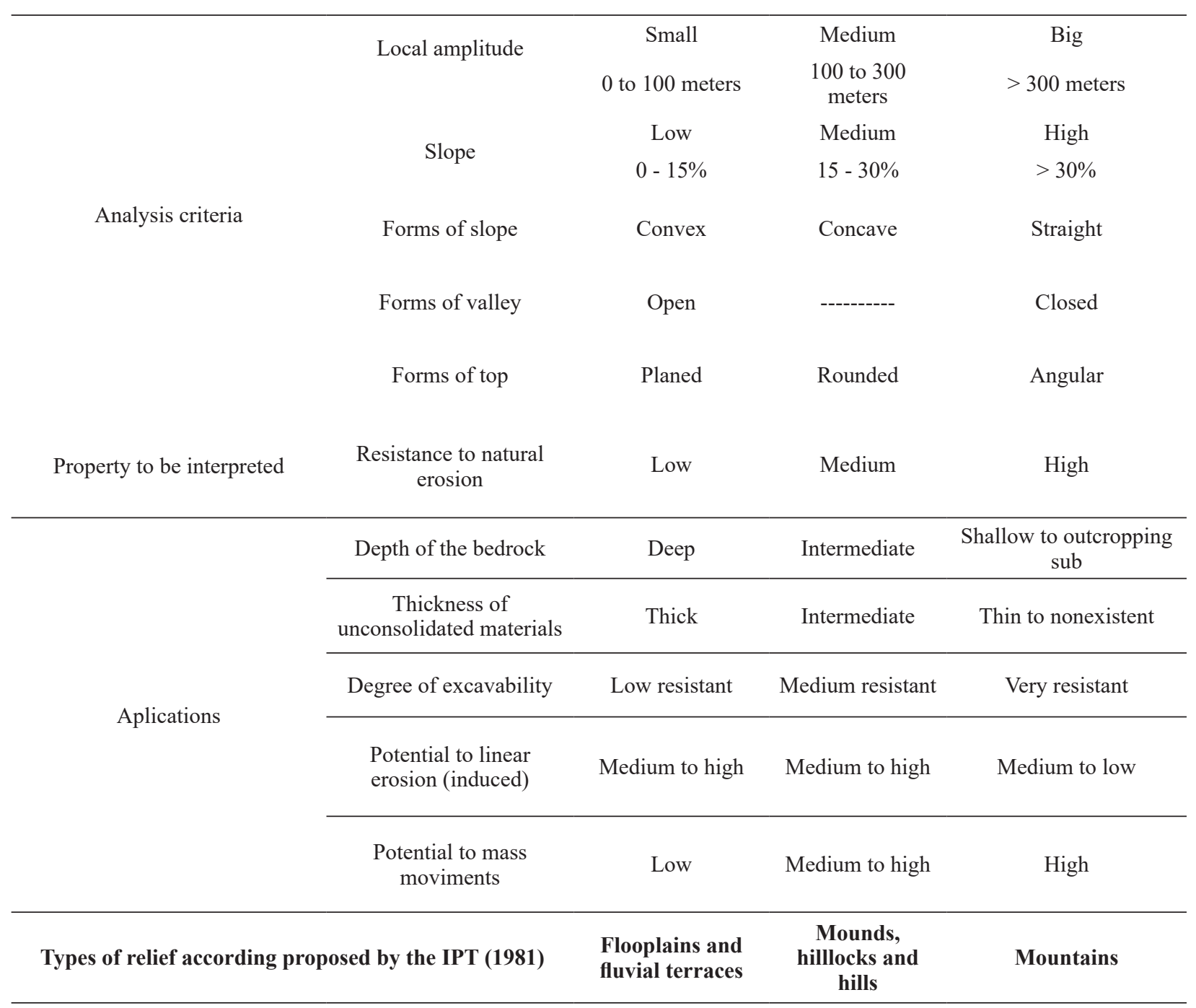


threshold was $99.9 \%$. This algorithm uses training samples to estimate the probability density function to the considered classes, and then evaluates the Bhattacharya distance between the classes for each region. This algorithm calculates the average distance between the probability distributions of two classes by considering the mean and covariance. For that, the chi-square statistic, which measures the difference between the distributions, is used as a criterion for a class to be rejected.

The Kappa index, which evaluates the concordance between the ground truth (field data) and the thematic map (Smits et al. 1999), was used to quantify the performance of the supervised classification. Cross-tabulation was performed to indicate the proportion of present or absent cases in the map, and the results are summarized as a significance matrix, in which the elements along the main diagonal indicate the classification significance. This step was performed in the SPRING 5.1.8. software (INPE 2011) through the "validation" module.

\section{GEO-ENVIRONMENTAL MAPPING}

Geo-environmental mapping is part of the landuse planning process, with homogeneous areas defined regarding to their natural characteristics and evaluated considering potential and limitations to determinate the needs for management or conservations, even as their tolerance to anthropic interventions. Thus, geo-environmental zones were established from the integration by overlaying of physiographic compartmentalization with landuse mapping. Thereby, the geo-environmental zoning consisted of the territorial division in homogenous units, according to the potentiality and susceptibility of the terrain to the occurrence of physical environment processes (such as slides, erosion and flooding), and the suitability of the land use in the topographic maps of São José dos Campos and Jacareí. Therefore, the method used for the geo-environmental zoning was mainly based on the studies of Fernandes-da-Silva and Cripps (2011), Zaine (2011), Fernandes-da-Silva et al. (2010), Da-Silva and Rodrigues-Carvalho (2006), Vedovello (2000), Vedovello and Mattos (1993, 1998), Soares and Fiori (1976).

To delimit the geoenvironmental zones and overlapping of the maps of physiographic compartmentation and land use, weights were first assigned for each layer, whose values ranged from 1 to 5, which indicate, in increasing order, very low up to very high susceptibility. The values for the physiographic compartmentalization were established according to the different vulnerabilities and characteristics of each unit and its potential to geological processes, such as mass movements, linear erosion and floods, associated with the respective slope values found in each one, as well as indications of the surface dynamics processes identified in the aerial image analysis and field investigations. In this context, several authors, such as Feizizadeh and Blaschke (2013), Elsheikh et al. (2015), Kong etal. (2016) and Ross (2006) have been using physiographic criteria and presence of surface dynamics processes as hierarchical parameters to obtain maps of environmental susceptibility and geo-environmental zoning, in which the method to overlay variables, such as slope, altimetry and geological units and geomorphological data, are selected as indicators for obtaining homogeneous units that synthesize their main potentialities and implications.

Therefore, physiographic units that presented processes of linear erosion, low slope and morphologies that range from mounds to hillocks, were attributed as units with low susceptibility; units with mean slope, mean amplitude and hill relief were indicated as medium susceptibility, and units with mountainous morphology with high slopes and dissected relief were identified as highly susceptible. Moreover, physiographic units with morphological characteristics linked to flooding 
processes were also classified as highly susceptible, since this type of geo-hydrological process can lead to damaging socio-economic damages.

The attribution of weights to land use classes followed the recommendations of Ross (2006) and Lepsch (2002), which establish different susceptibilities of the forms of occupation in relation to their vulnerability to processes of surface dynamics. In this context, areas with higher forest density have lower vulnerability and received lower weights (1), farmyard areas were selected as weight 2, urbanized areas with forestry by Eucalyptus sp. were indicated with weight 3 , areas with presence of rice culture and pasture received weight 4 and, finally, mining areas were established as weight 5 (Ross 2006, Lepsch 2002).

The maps were overlaid in the ArcGIS 10.1 environment by using multicriteria analysis with a raster calculator and reclassification tools. Multicriteria analysis, also known as a weighted average, is the most used method in spatial analysis. In this method, each piece of surface information receives a relative weight to its importance, according to the established criteria for the project.

\section{RESULTS AND DISCUSSION}

\section{PHYSIOGRAPHIC COMPARTMENTALIZATION}

Nineteen physiographic units were found in the study area, distributed over floodplains, the Médio Paraíba Depression and Morpho-Sculptural Units of the Atlântico Plateau, the Mantiqueira Hills, the Paraitinga/Paraibuna Plateau and the plateau in the Central Paraíba Valley (Ross and Moroz, 1997) (Figure 4). Tables II and III show the results from the photoanalysis, photointerpretation and geological-geotechnical characteristics based on Zaine (2011).

For unit 1 (mica schists, quartz mica schists, quartzites and quartz schists in hilly relief), the photoanalysis and photointerpretation displayed that the textural density of the drainage elements and relief is high; thus, the intergranular permeability is low. The forms of the slopes in this unit range from concave to straight, and the slope values are high. Hence, the potential for mass movements and the runoff/infiltration ratio are high, which indicates a favorable region for mass movements, mainly landslides and creep.

Unit 2 (migmatites in hilly relief) has high relief density and drainage, so the chart by Zaine (2011) indicates that the permeability is low and the runoff/infiltration ratio is high. The local amplitudes are high and are related to slopes that ranged from concave to straight, whose slopes are high. According to the "Applications" item in the chart by Zaine (2011), the potential for gravitational movements is high and the processes that can occur include mass movements. Compared to unit 1 , the migmatites tend to form deeper soil profiles with boulders and rocky blocks.

In unit 3 (migmatites in mountainous relief), the photointerpretation process showed that the textural density is high; thus, the density of the relief and drainage is high (Table I). The permeability is low and the runoff/infiltration ratio is high. According to an analysis of the relief and its characteristics, this unit has high local amplitude and straight and high slopes beyond angular tops. The geotechnical characteristics of this unit indicate a high potential for gravitational movements, which mainly include blocks and landslides because of the boulders in the soil profile.

In unit 4 (migmatites in hillock relief), the density of the drainage and relief are intermediate, so the permeability and runoff/infiltration ratio are intermediate. The slope and local amplitude values are also intermediate; the slopes are concaves and the tops are rounded. In terms of the geologicalgeotechnical properties of this unit, the potential for linear erosion ranges from intermediate to low, as does the potential for gravitational movements because of more developed soil, which is associated with intermediate slopes. 

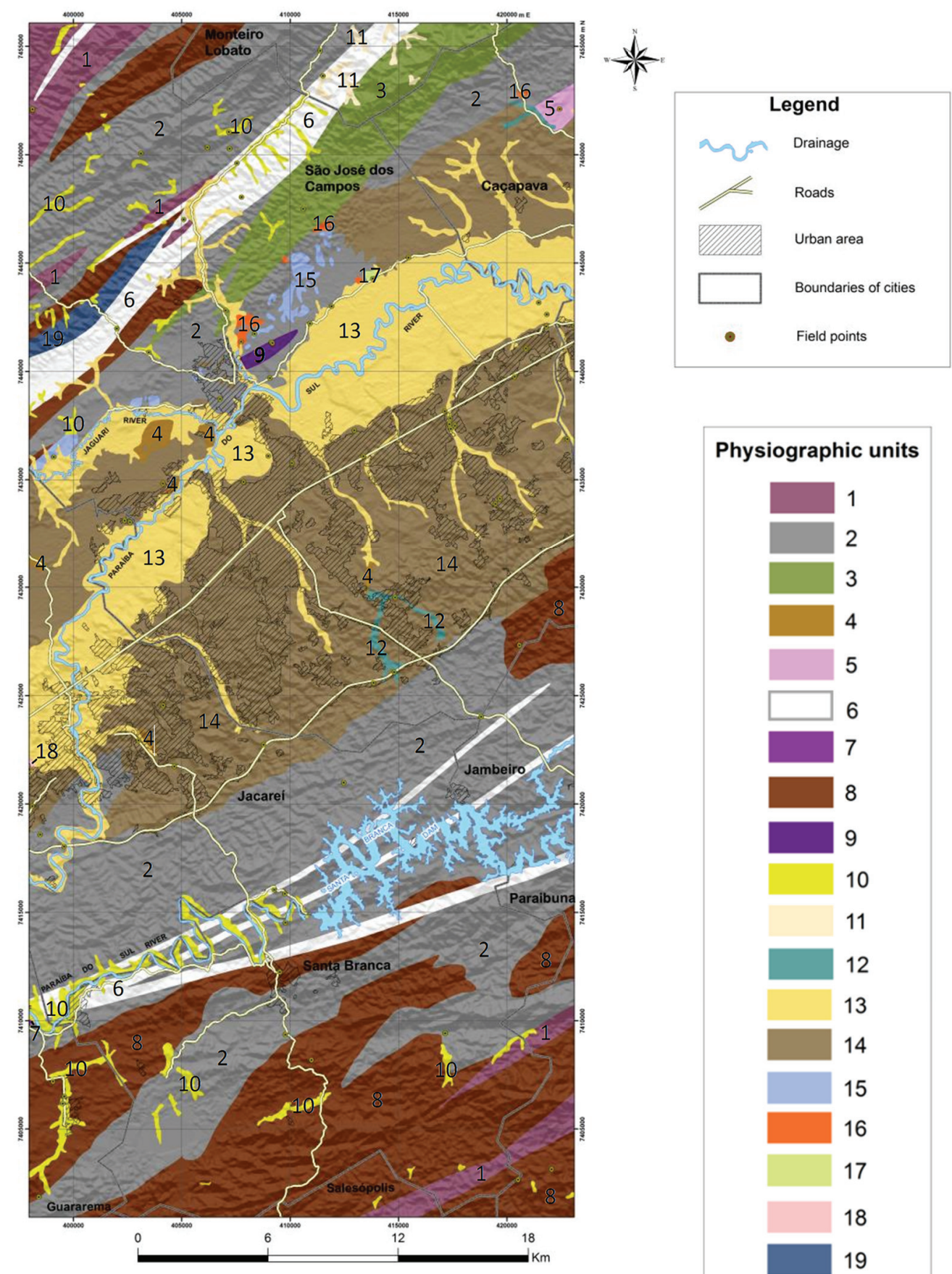

\section{Physiographic units}

\begin{tabular}{|l|l|}
\hline & 1 \\
\hline & 2 \\
\hline & 4 \\
\hline & 5 \\
\hline 6 \\
\hline 7 \\
\hline & 8 \\
\hline 9 \\
\hline 10 \\
\hline 11 \\
\hline 12 \\
\hline 13 \\
\hline 14 \\
\hline 16 \\
\hline 16 \\
\hline
\end{tabular}


Figure 4 - Physiographic compartmentalization of the study area. 


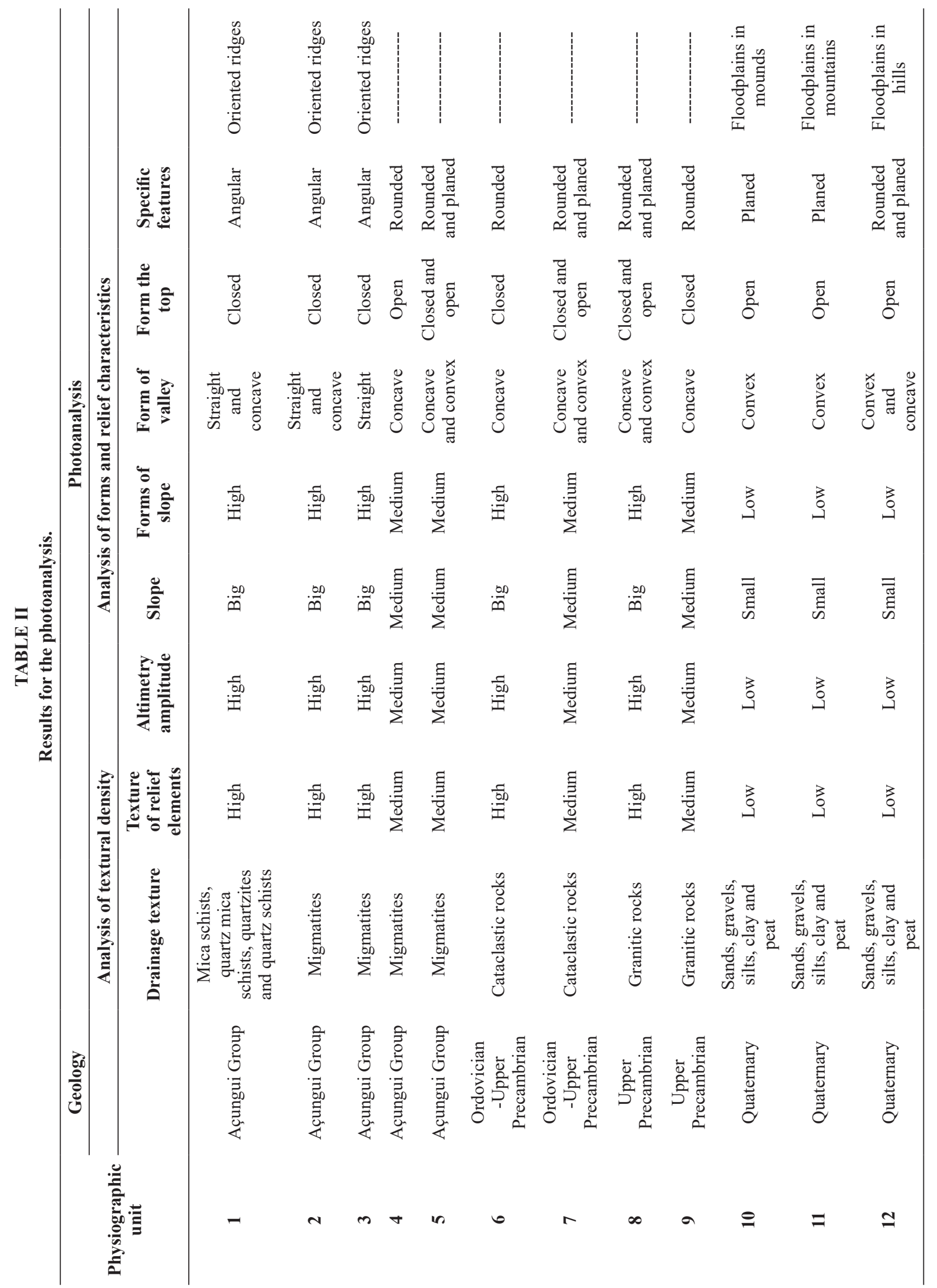




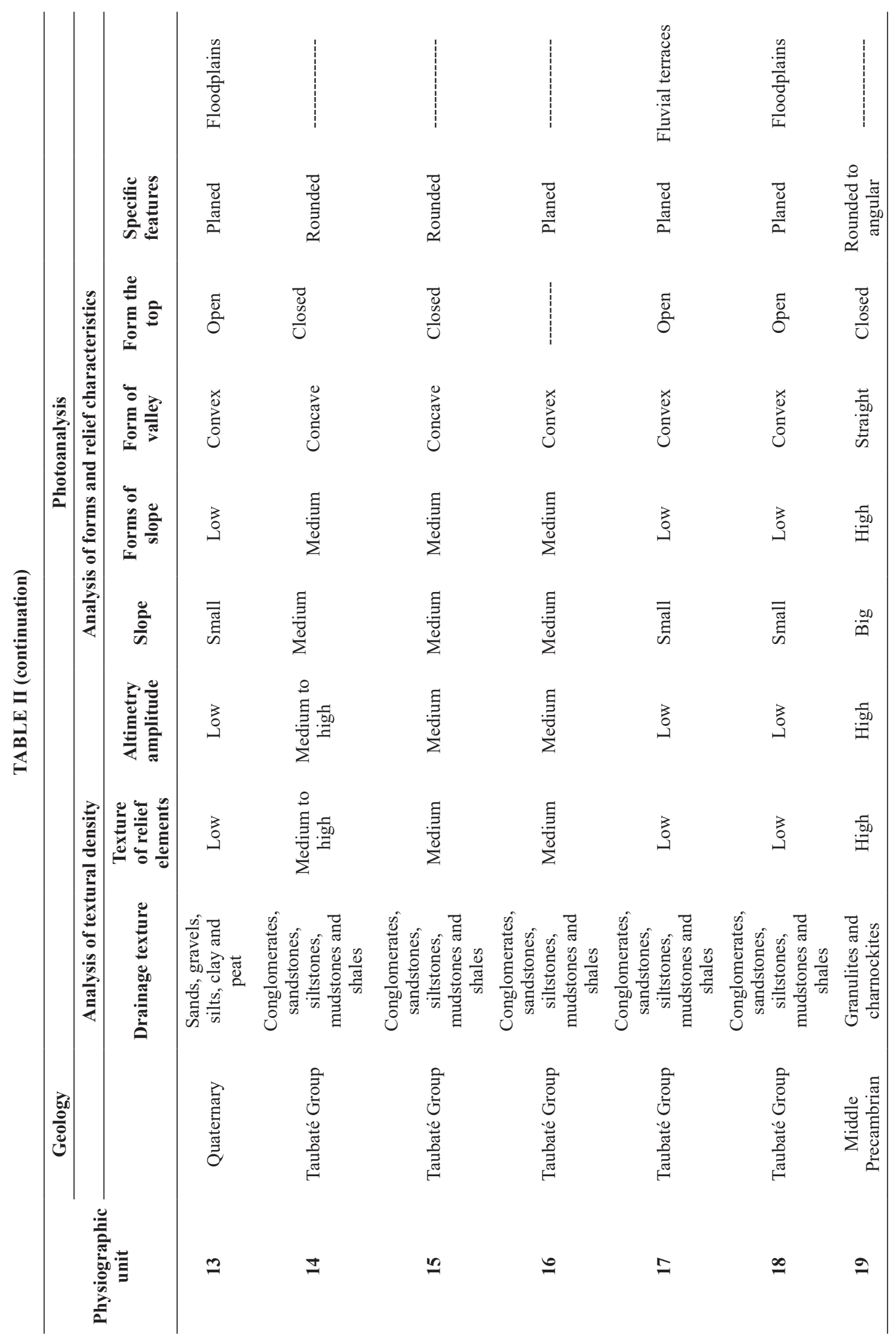


For unit 5 (migmatites in mound relief), the photointerpretation process showed that the density of the drainage and relief, the local amplitude and the slope are intermediate. The permeability and the runoff/infiltration ratio are intermediate. The forms of the slopes range from concave to convex, and the tops can be planar or rounded. The geologicalgeotechnical properties indicate that the potential for linear erosion ranges from intermediate to high, while the probability of gravitational movements is intermediate.

For unit 6 (cataclastic rocks in hilly relief), the textural density is high because of the high density of the drainage and relief. Thus, this unit has a low permeability and a high runoff/infiltration ratio. The local amplitude and the slope values are high, with the forms of the slopes exhibiting concave-straight patterns with rounded tops. The potential for linear erosion and gravitational movements ranges from intermediate to high.

For unit 7 (cataclastic rocks in mounds), the density of the drainage and relief are intermediate, which causes the permeability and runoff/infiltration ratio to be intermediate. The forms of the slopes range from concave or convex, and the values of the slopes and local amplitudes are intermediate, with rounded or straight tops. According to the chart by Zaine (2011), the potential for gravitational movements is intermediate, but the potential for linear erosion ranges from intermediate to high.

For unit 8 (granitic rocks in hills), the high density of the drainage and relief creates a region with a high runoff/infiltration ratio. Thus, the forms of the slopes are concave and convex with high values, and the unit shows mass movements throughout its length.

For unit 9 (granitic rocks in mound relief), the textural density is intermediate because of the intermediate density of the relief and drainage. Thus, the permeability and the runoff/infiltration ratio are intermediate. The local amplitude and the values of the slope are intermediate, and the slopes show concave forms with rounded tops. The potential for linear erosion and gravitational mass are intermediate.

Unit 10 (Quaternary sediments in hilly relief) is present throughout the study area and, despite being located in hilly relief, is present as small floodplains with low slopes and local amplitudes and open yet restricted valleys. The geological process that occurs most often is fluvial erosion, which includes the undermining of river banks beyond siltation and flooding.

Unit 11 (Quaternary sediments in mountainous relief) is distributed as small floodplains with low slopes and local amplitudes and open yet restricted valleys. Similar to the previous unit, the main geological processes that occur in this unit are fluvial erosion, the undermining of river banks, siltation and flooding. However, the velocity of the process can be differentiated in each unit because unit 11 is located in mountainous relief, in which the slopes are straight and steep; thus, the entrainment of sediments tends to be more intense and faster, which enables the formation of flood waves in drainage beds.

In unit 12 (Quaternary sediments in hillock relief), the textural density is intermediate because of the intermediate density of the relief and drainage. Thus, the permeability and the runoff/infiltration ratio are intermediate. The local amplitudes and slopes are low, in which the valleys are open with convex to concave slopes. Thus, the potential for linear erosion is intermediate to high.

In unit 13 (Quaternary sediments in floodplains), the photointerpretation step showed low densities for the drainage and relief and thus low textural density. The permeability is high and the runoff/ infiltration ratio is low. The analysis of the relief shows low local amplitudes and low slope values, with open valleys and plain surfaces. The potential for linear erosion is high. Fluvial erosion and floods have occurred in this unit. This place has urban areas with big cities, such as São José 
dos Campos and Jacareí, and engineering works are frequently performed to mitigate the problem of flooding. However, the disorderly occupation, mainly in the areas close to the Paraíba do Sul River, aggravates the problem of flooding because no adequate infrastructure exists for housing.

In unit 14 (conglomerates, sandstones, siltstones, mudstones and shales in hillock relief in the Taubaté Group), the photointerpretation activities showed intermediate to high density of the drainage and relief. Thus, the runoff/infiltration ratio ranges from intermediate to high, while the permeability ranges from intermediate to low. The local amplitude and slope are intermediate, with concave slopes and closed valleys. According to its geological-geotechnical characteristics, the potential for linear erosion and gravitational movements is intermediate.

Unit 15 (conglomerates, sandstones, siltstones, mudstones and shales in hilly relief in the Taubaté Group) shows intermediate density of the drainage and relief. The permeability and runoff/ infiltration ratio are intermediate. In terms of the forms and characteristics of the relief, the local amplitude and the slope have intermediate values, and the forms of the slopes are concave with rounded tops. According to its geological-geotechnical characteristics, the potential for linear erosion and gravitational movements ranges from intermediate to high. The field work observed linear erosion (as gullies and ravines) and creeping.

In unit 16 (conglomerates, sandstones, siltstones, mudstones and shales in mound relief in the Taubate Group), the textural density is intermediate and the relief density, which indicates the dissection and roughness of the terrain, is intermediate. Thus, the permeability and the runoff/ infiltration ratio are intermediate. The analysis of the forms and relief characteristics indicates that the local amplitude and the values of the slopes are intermediate. The forms of the tops are planar. The unit has intermediate to high potential for linear erosion and gravitational movements, such as landslides.

In unit 17 (conglomerates, sandstones, siltstones, mudstones and shales in fluvial terraces in the Taubate Group), the textural density is low because of the low density of the relief and drainage. The permeability and runoff/infiltration ratio are low. According to the forms and relief characteristics, the photointerpretation step indicated low local amplitudes and slopes. The forms of the tops are rounded and the particular features of the relief include fluvial terraces. The geological-geotechnical characteristics indicate that the potential for linear erosion in this unit ranges from intermediate to high; gullies were observed in some isolated points during the field work. The potential for gravitational movements is low because the slopes are gentle.

In unit 18 (conglomerates, sandstones, siltstones, mudstones and shales in floodplains in the Taubaté Group), the textural density is low because of the low density of the relief elements and drainage. Thus, the permeability is high and the runoff/infiltration ratio is low. The local amplitude and the slope have low values. The tops are planar and the particular features of relief include floodplains. Thus, the geologicalgeotechnical characteristics of this unit display a high potential for linear erosion and a low potential for gravitational movements.

Finally, in unit 19 (granulites and charnockites in hilly relief), the textural density is high because of the high density of the drainage and relief. According to Zaine's (2011) study, the permeability is low. The analysis of the forms and relief characteristics indicated high local amplitudes and high slope values. The forms of the slopes are straight, with closed valleys alongside rounded tops. In this unit, the potential for gravitational movements is high and the potential for linear erosion ranges from intermediate to low. 


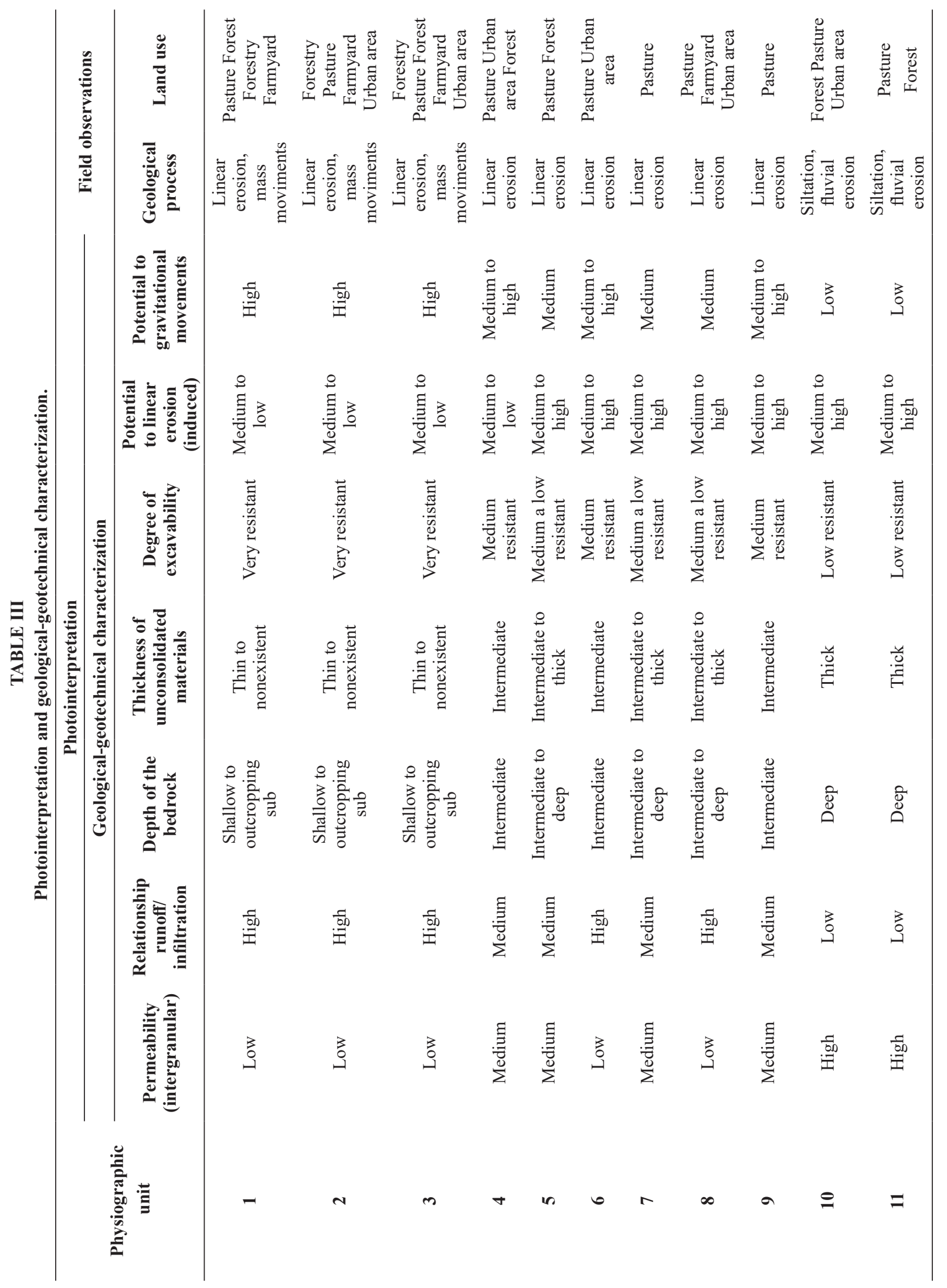




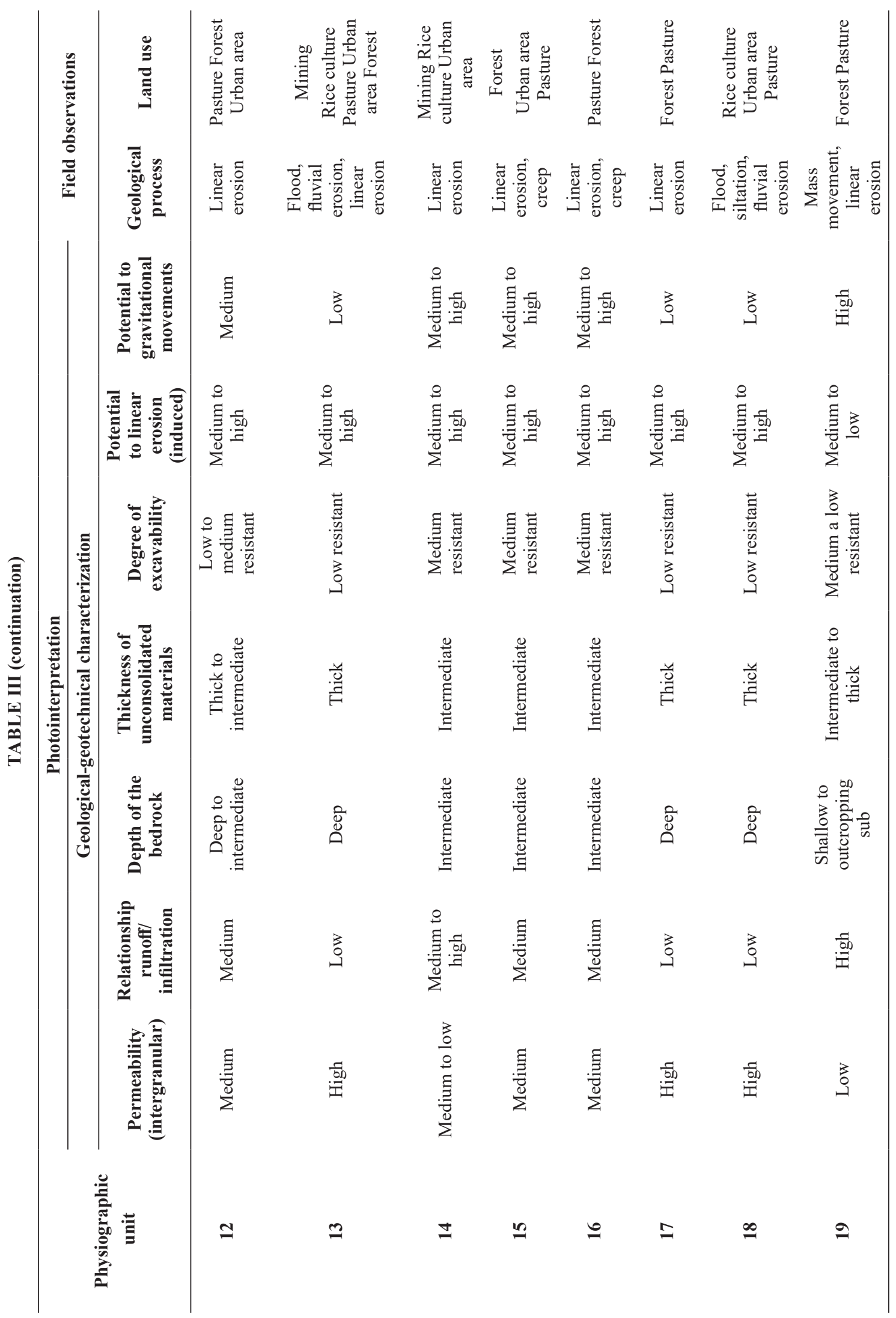


In general, the units that are located in mountainous regions (units 1, 2, 3, 16 and 19) have potential for mass movements, such as creep, landslides and debris flow. These units are geologically located in the vicinity of a crystalline basement, which has high textural density, high slopes, high amplitudes and angular tops. In terms of specific features, these units have oriented ridges that inhibit anthropic activity. It is recommended that these areas follow the directions of the Brazilian Forest Law, which establishes that areas with slopes greater than $45^{\circ}$ and mountain tops must have forests (Brazil 2012).

The units that are located in mound and hilly regions (units 4, 5, 7, 9, 12,14,15,17) may be located both in the domain of a crystalline basement or in sedimentary rocks (Taubaté Group). The geological processes that can occur involve linear erosion, such as erosive furrows and gullies. For these units, the main characteristics are intermediate slopes, intermediate textural density and rounded tops. As these units have pastures as the main land use, it is recommended that the vegetation be reconstituted and that forest fragments be restored.

The units in the floodplain and fluvial terrace regions (units 10, 11, 12, 13 and 18) are both in the domain of sedimentary rocks or Quaternary sediments (sands, gravels, silts, clay and peat). The geological processes that occur in these areas are mainly floods, siltation and fluvial erosion. These areas have mining and rice culture as their main land uses, which can initiate or accelerate these geological processes. The region of the Paraíba do Sul Valley is very important nationally for the mining of sands. In 1999, the Departamento do Ambiente do Estado de São Paulo established the environmental zone for sand mining, which divides the floodplain of the Paraíba do Sul River into areas for the protection and conservation of forest (Departamento do Ambiente do Estado de São Paulo 1999). Thus, following these guidelines is very important so that geological processes are minimized.

Fernandes-da-Silva et al. (2010), who used the same methodology, called the physiographic units "Basic Compartmentalization Units", or BCUs, where each unit was analyzed by tectonic discontinuities, the bedrock lithology, the soil profile, the slope steepness and the water table depth through remote sensing techniques. Similarly, Cardoso et al. (2009), who used the same terminology ("Basic Compartmentation Units"), performed physiographic compartmentalization through the analysis and identification of the textural elements of relief and drainage with remote sensing images. Fontes and Pejon (2008), who used the technique known as the "Ottobasin Method", performed compartmentalization through physical environmental attributes. Variables such as the rock substrate, landforms, unconsolidated material and slope were used for this compartmentalization, in which the homogeneity of each basin and interbasin was evaluated. In this article, the units were called "Physiographic Units" and their characterization was performed according to the variables in Table I. This method is based on the textural elements of relief and drainage, and the geotechnical data are performed through a correlation with inferences from other information (Vedovello 2000). The main advantage of this method is the development of a single cartographic product from the integration of physical environmental elements in "Basic Compartmentalization Units" - BCU's. This compartmentalization technique with field descriptions facilitates the establishment of physiographic characteristics and enables us to extend the considerations to the various compartments (Oliveira 2004).

\section{LAND-USE MAPPING}

Nine land-use classes were determined according to a preliminary image analysis, following 
assumptions by the IBGE (2006). Validation was performed by the Kappa index, whose result was 0.86 , which is considered to be significant according to Smits et al. (1999).

In general, major urban centers are concentrated in the Taubaté Sedimentary Basin along the floodplain and fluvial terraces of the Paraíba do Sul River and comprise $9.8 \%$ of the total area. In these regions, the forest is very limited, restricted to only a few fragments in the belts of river meanders. In this area, large rice cultures, which correspond to $5.53 \%$ of the total study area, can be found beyond forests.

The floodplain also highlights areas that are occupied by mining activities, specifically, sands and clays. According to Rampanelli et al. (2011), these materials have been actively extracted from the Paraíba do Sul Valley over the last 50 years.

The urban area of São José dos Campos has a large native Cerrado spot that is located on its eastern side and comprises $0.13 \%$ of the total area.

The areas that are located in the crystalline basement are occupied by pastures and forests. However, small villages are sometimes found next to the Santa Branca dam and the small city of Santa Branca, which is situated in the riverbank of the
Paraíba do Sul River. The pastures and forests correspond to $59.70 \%$ and $13.11 \%$ of the total area, respectively.

The continental water class refers to small dams, the Santa Branca dam, the Jaguari River and the Paraíba do Sul River, which correspond to $2.17 \%$ of the area. Farmyard fragments, which are also called secondary vegetation and have a shrubby character, are sometimes found along the Santa Branca dam. These areas correspond to $1.85 \%$ of the whole area, with a large distribution around the Santa Branca dam.

Finally, forests have a large distribution but are concentrated in the southern region of the Santa Branca dam and correspond to $7.45 \%$ of the total area. Figure 5 shows the distributions of each class in relation to the total area, and Figure 6 shows the land-use mapping results.

\section{GEO-ENVIRONMENTAL ZONING}

Geo-environmental zones were set from the integration of overlaid maps from physiographic compartmentalization and data from land-use mapping and land cover. This mapping consisted of divided homogeneous units, including the potential for and susceptibility of the land to the occurrence

\section{Distribution of land use classes}
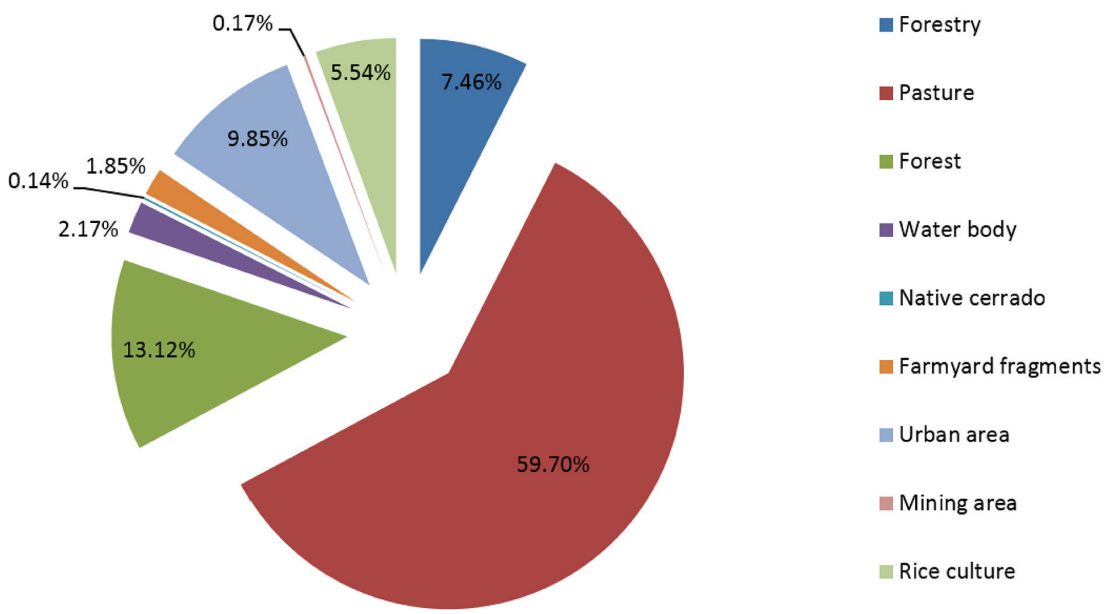

Figure 5 - Distribution of land-use classes in the study area. 


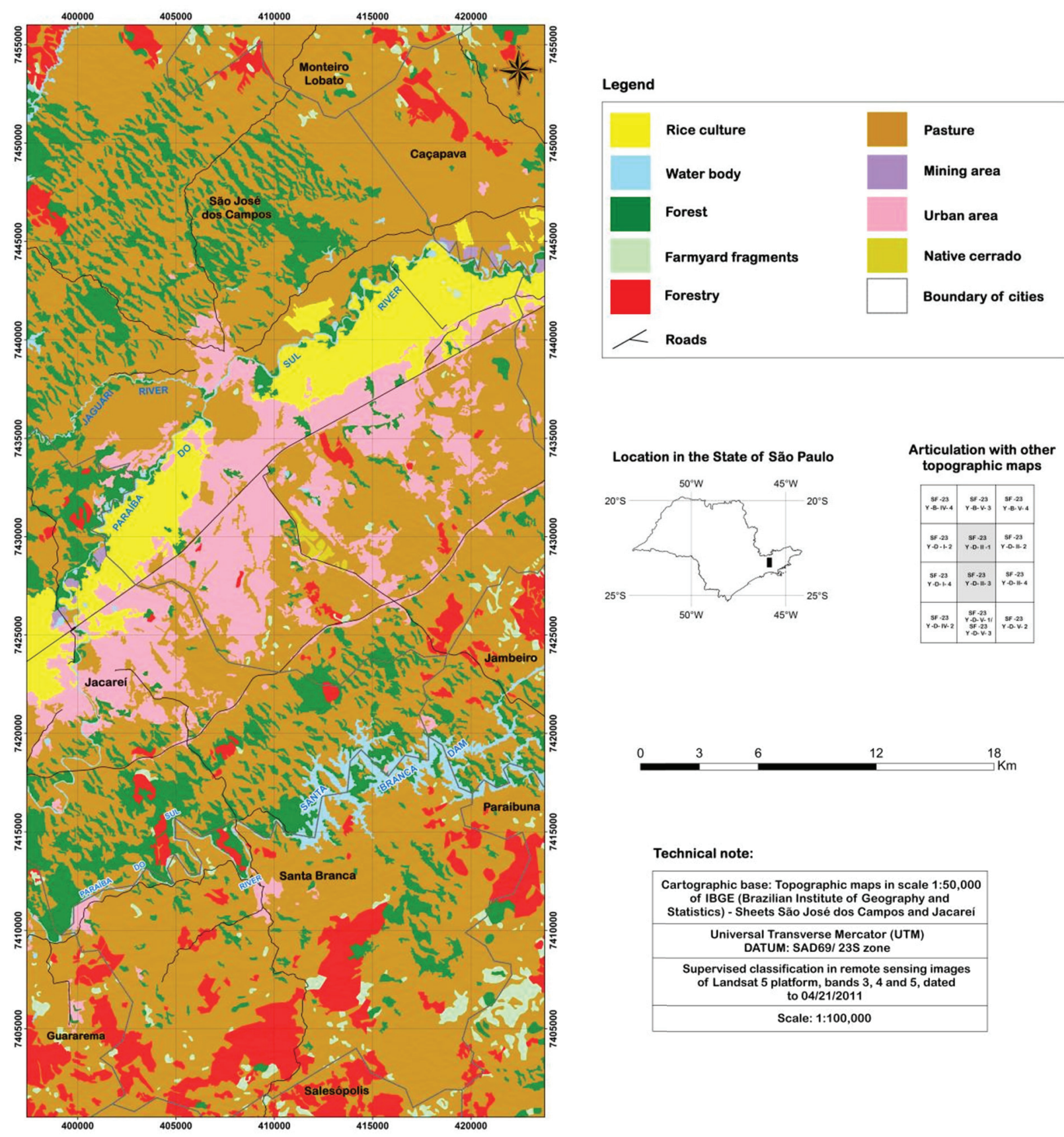

Figure 6 - Land-use mapping in the study area.

of physical environmental processes (such as mass movements, erosion and flooding) and the suitability of land use in the São José dos Campos and Jacareí (SP) regions.

In relation to the attribution of the weights for the physiographic compartmentalization, units with weights of 1 have slopes of less than $10 \%$ and therefore display low potential for the occurrence of physical environmental processes, such as floods, erosion or mass movements. The physiographic unit that shows this characteristic is unit 16. In this context, a weight of 2 is represented by units with 
low slopes, mound relief and sandstone formation, which may facilitate the occurrence of linear erosion. The unit that fits in this profile is unit 12, whose main geological process is linear erosion. A weight of 3 was assigned to units that have intermediate potential for geological processes and whose characteristics are intermediate slopes, intermediate amplitudes and mound and hilly relief. The units that have these characteristics are 4, 5, 7 and 9, which are located in the crystalline basement. A weight of 4 is represented by units that have high potential for linear erosion, intermediate slopes and mound and hilly relief. The units that have these characteristics are 14 and 15, which are located in the Taubaté Group. Finally, a weight of 5 was assigned to units with higher susceptibility to geological processes, which comprise two categories. The first includes units that have low slopes, areas that are subject to flooding and silting, and unconsolidated soils with low bearing capacity. This category comprises the units $10,11,13,17$, and 18, which are located in the Taubaté Group (17 and 18) and Quaternary sediments (10, 11, and 13). The other category refers to units that have high slopes (greater than 30\%) and high potential for the occurrence of dynamic surface processes (landslides, creep and bearing blocks). These units include $1,2,3,6,8$, and 19, which are situated in the crystalline basement.

The land-use values were established according to Ross (2006) and Lepsch (2002), and these classes were set according to the land-use weakness. Tables IV and V show the weights that were assigned for the land use and the physiographic units in the study area. Thus, 7 geo-environmental units were obtained, as shown in Figure 7 and in the table VI. The following topics describe the main features of each unit.
TABLE IV

Weights for land use according Lepsch (2002) and Ross (2006).

\begin{tabular}{cc}
\hline Class & Weight \\
\hline Forest & 1 (very weak) \\
Farmyard & 2 (weak) \\
Urban area and forestry & 3 (medium) \\
Pasture and rice culture & 4 (strong) \\
Mining areas & 5 (very strong) \\
\hline
\end{tabular}

TABLE V

Physiographic units weighting.

\begin{tabular}{|c|c|c|}
\hline Weight & $\begin{array}{l}\text { Physiographic } \\
\text { units }\end{array}$ & $\begin{array}{l}\text { Characteristics for the } \\
\text { definition of weights }\end{array}$ \\
\hline \multirow{3}{*}{$\begin{array}{c}1 \\
\text { (very low } \\
\text { susceptibility) }\end{array}$} & \multirow{3}{*}{16} & $\begin{array}{c}\text { - Low slopes (less than } \\
10 \%)\end{array}$ \\
\hline & & $\begin{array}{l}\text { - Low potential for } \\
\text { occurrence of processes } \\
\text { physical environmental }\end{array}$ \\
\hline & & - Low slopes \\
\hline $\begin{array}{c}2 \text { (low } \\
\text { susceptibility) }\end{array}$ & 12 & $\begin{array}{l}\text { - Relief of mounds } \\
\text { - Sandstone formation } \\
\text { may facilitate the } \\
\text { occurrence of linear } \\
\text { erosion }\end{array}$ \\
\hline \multirow{3}{*}{$\begin{array}{c}3 \text { (medium } \\
\text { susceptibility) }\end{array}$} & \multirow{3}{*}{$4,5,7,9,14$} & - Medium slopes \\
\hline & & - Medium amplitudes \\
\hline & & $\begin{array}{l}\text { - Relief of mounds and } \\
\text { hills }\end{array}$ \\
\hline \multirow{3}{*}{$\begin{array}{c}4 \text { (high } \\
\text { susceptibility) }\end{array}$} & \multirow{3}{*}{$10,11,15$} & - Dissected relief \\
\hline & & - Medium slopes \\
\hline & & $\begin{array}{l}\text { - Relief of hills to } \\
\text { mountains }\end{array}$ \\
\hline \multirow{5}{*}{$\begin{array}{l}5 \text { (very high } \\
\text { susceptibility) }\end{array}$} & \multirow{3}{*}{$13,17,18$} & - Low slopes \\
\hline & & $\begin{array}{l}\text { - Areas subject to } \\
\text { flooding and silting }\end{array}$ \\
\hline & & $\begin{array}{l}\text { - Unconsolidated } \\
\text { soils with low bearing } \\
\text { capacity }\end{array}$ \\
\hline & & $\begin{array}{l}\text { - High slopes (more than } \\
30 \% \text { ) }\end{array}$ \\
\hline & $1,2,3,6,8,19$ & $\begin{array}{l}\text { - High potential for } \\
\text { occurrence of dynamic } \\
\text { surface processes } \\
\text { (landslides, erosion and } \\
\text { bearing blocks) }\end{array}$ \\
\hline
\end{tabular}






Figure 7 - Geo-environmental zoning in the study area. 
TABLE VI

Chart of characteristics of geoenvironmental zones.

\begin{tabular}{|c|c|c|c|}
\hline $\begin{array}{c}\text { Geoenvironmental } \\
\text { zones }\end{array}$ & $\begin{array}{l}\text { Susceptibility to } \\
\text { geological process }\end{array}$ & $\begin{array}{l}\text { Main characteristics of } \\
\text { geoenvironmental zones }\end{array}$ & Recommendations \\
\hline A1 & \multirow[t]{2}{*}{ Low } & $\begin{array}{l}\text { - Forests along some drainages and } \\
\text { features smooth relief with low slopes } \\
\text { - Areas under intense pressure from } \\
\text { the surrounding agricultural activities }\end{array}$ & $\begin{array}{l}\text { - Preserve the forests and } \\
\text { fragments, especially to serve as } \\
\text { a legal reserve of properties that } \\
\text { are included in legislation (Brazil } \\
\text { 2012) } \\
\text { - Increase the integration of } \\
\text { the fragments through the } \\
\text { establishment of ecological } \\
\text { corridors }\end{array}$ \\
\hline A2 & & $\begin{array}{l}\text { - Isolated points of early stages of } \\
\text { linear erosion, especially in places } \\
\text { with high slopes (greater than } 30 \% \text { ) } \\
\text { - Large patches of remnant forest and } \\
\text { secondary vegetation (farmyard) }\end{array}$ & $\begin{array}{l}\text { - Preserving these forests and } \\
\text { fragments and restoring secondary } \\
\text { vegetation, especially on slopes } \\
\text { that are greater than } 20^{\circ}\end{array}$ \\
\hline $\mathrm{B}$ & Low to medium & $\begin{array}{l}\text { - Areas occupied by large pastures, } \\
\text { rice culture and urban zones } \\
\text { - The linear erosion is the most } \\
\text { frequent geodynamic process, which } \\
\text { occurs in the form of erosive furrows } \\
\text { and gullies } \\
\text { - Periodic flooding may occur during } \\
\text { periods of heavy rain, especially in } \\
\text { locations near the floodplain of the } \\
\text { Paraíba do Sul River }\end{array}$ & $\begin{array}{l}\text { - Caution is recommended in } \\
\text { regions of rice cultures and } \\
\text { pastures. This rice culture is a } \\
\text { highly polluting and the pastures, } \\
\text { if no good management practices } \\
\text { exist, can accelerate erosion } \\
\text { - The expansion of urban areas } \\
\text { should mainly be controlled near } \\
\text { the floodplain of the Paraíba do } \\
\text { Sul River }\end{array}$ \\
\hline $\mathrm{C}$ & Medium & $\begin{array}{c}\text { - Dissected relief } \\
\text { - Medium slopes } \\
\text { - Relief of hills to mountains }\end{array}$ & $\begin{array}{l}\text { - Caution is recommended for the } \\
\text { projects that are to be implemented } \\
\text { in these places, especially on } \\
\text { slopes above } 20^{\circ}\end{array}$ \\
\hline $\mathrm{D}$ & High & $\begin{array}{c}\text { - Low and high slopes } \\
\text { - Areas located in the floodplain of the } \\
\text { Paraíba do Sul are subject to flooding } \\
\text { and silting } \\
\text { - In the region of the crystalline } \\
\text { basement the main geological } \\
\text { processes are mass movements and } \\
\text { linear erosion }\end{array}$ & $\begin{array}{c}\text { - The floodplain of the Paraíba } \\
\text { do Sul region is protected by the } \\
\text { Environmental Protection Area } \\
\text { of "Banhado" and by the Zoning } \\
\text { Mining Environmental of Paraíba } \\
\text { do Sul River } \\
\text { - The region of the crystalline } \\
\text { basement should be sheltered from } \\
\text { anthropic use and designated as } \\
\text { Permanent Preservation Areas to } \\
\text { minimize the geological processes }\end{array}$ \\
\hline $\mathrm{E}$ & Very high & $\begin{array}{l}\text { - Mining areas of sand in the } \\
\text { floodplain of the Paraíba do Sul River } \\
\text { - High potential for occurrence of } \\
\text { siltation, fluvial erosion and floods }\end{array}$ & $\begin{array}{c}\text { - The geological processes } \\
\text { that occur at this site should be } \\
\text { frequently monitored } \\
\text { - Forest recovery should } \\
\text { be realized to reduce the } \\
\text { aforementioned geological } \\
\text { processes }\end{array}$ \\
\hline
\end{tabular}




\section{Geo-environmental zone A}

Geo-environmental zone A refers to areas that have low potential for geological processes. This zone was divided into two sub-sections: A1 and A2. Geo-environmental sub-section A1 corresponds to areas that don't have processes related to flooding, erosion and mass movements, mainly due to protection of woody vegetation and the low natural susceptibility of the physical environment to the aforementioned processes. This area refers to the forests along some drainages and features smooth relief with low slopes, which forms isolated forest fragments that are distributed throughout the study area. This subzone, which is under intense pressure from surrounding agricultural activities, has historically made progress in forest areas.

Preserving these forests and fragments is recommended, especially to serve as a legal reserve of properties that are included in legislation (Brazil 2012), but also to increase their integration through the establishment of ecological corridors.

Although geo-environmental sub-section A 2 has forest remnants in its interior, the region sometimes contains areas with isolated points of early stages of linear erosion, especially in places with high slopes (greater than 30\%). However, mass movements are not common in this locale.

This subarea has low sensitivity to physical environment processes because of large patches of remnant forest and secondary vegetation (farmyard). Notwithstanding, preserving these forests and fragments and restoring secondary vegetation, especially on slopes that are greater than $20^{\circ}$, is highly recommended.

\section{Geo-environmental zone B}

Geo-environmental zone B mainly occurs near the sedimentary Taubate Basin and is occupied by large pastures, rice culture and urban areas. This zone's susceptibility to geological process is low to medium, and linear erosion is the most frequent geodynamic process, which occurs in the form of erosive furrows and gullies. Flooding may occur during periods of heavy rain, especially in locations near the floodplain of the Paraíba do Sul River. This area does not have potential for mass movements.

Caution is recommended in regions of rice cultures and pastures. This rice culture is a highly polluting activity because of the amount of pesticides used for pest control, and the pastures, if no good management practices exist, it can accelerate erosion.

The urban sprawl should mainly be controlled near the floodplain of the Paraíba do Sul River. This place is located in the Environmental Protection Area (EPA) ofBanhado and the EPA of the watershed of the Paraíba do Sul River. The EPA of Banhado aims to protect the floodplain of the Paraíba do Sul River. Nevertheless, prohibited activities are present at this site, such as the parceling of land for urban purposes, the installation of polluting industries, the expansion of industrial areas, the use of techniques that are capable of causing soil erosion from land or the silting of water, the removal of existing vegetation cover, mineral exploration and the use of the area for recreational farm management (CETESB 2002).

\section{Geo-environmental zone C}

Geo-environmental zone $\mathrm{C}$ has medium potential for geological processes. This region mainly occurs in forestry and pastures. In this location there is an Environmental Protection Area (EPA) of the watershed of the Paraíba do Sul River, which mainly proposes measures for its recovery. Thus, the EPA, in accordance with current legislation, is an extensive area with a certain degree of human occupation, including abiotic, biotic, aesthetic and cultural attributes, which are especially important for the quality of life and well-being of human populations, even as aims to protect biological 
diversity, discipline the occupation process and ensure the sustainable use of natural resources.

Thus, sustainable development should be conducted in this region to reconcile human occupation and biological diversity. This zone is mainly distributed in the crystalline basement region, where the slopes are higher and the potential for mass movements is high. Thus, caution is recommended for the projects that are to be implemented in these places, especially on slopes above $20^{\circ}$.

\section{Geo-environmental zone D}

Geo-environmental zone D has high potential for geological process. This zone is present in the entire study area, mainly in pastures. In the floodplain of the Paraíba do Sul region, where the land use is mainly urban area and rice culture, the most common geological processes are floods, siltation and fluvial erosion. These places are protected by the EPA of "Banhado" and by the Zoning Mining Environmental of Paraíba do Sul River, which aims to harmonize economic development and protect natural resources.

In this region of the crystalline basement, which contains this geo-environmental zone, the main geological processes are mass movements and linear erosion. These sites should be sheltered from anthropic use and designated as Permanent Preservation Areas to minimize these processes (Brazil 2012).

\section{Geo-environmental zone E}

Geo-environmental zone E has high potential for geological processes and refers to mining areas of sand in the floodplain of the Paraíba do Sul River. The most common geological processes are siltation, fluvial erosion and floods.

The mining of sand has been a major cause of negative environmental impacts, such as silting, changes in the courses of rivers, changes in drainage, erosion, mass movements, the alteration of the surface topography and landscape, the transport of extracted material, excessive dust and vibration, and soil compaction. Other low intensity impacts to the physical environment include solid residues from sifting processes and noise from extraction equipment, loading and transportation. Furthermore, mining activities also cause the removal of vegetation and the loss and destruction of fertile topsoil.

The geological processes that occur at this site, such as siltation and floods, should be frequently monitored. This zone is included in the EPA of "Banhado" and in the protection, floodplain conservation and recovery zones of the Mining Zoning. Thus, forest recovery should be realized to reduce the aforementioned geological processes.

The methodology used in the present work, with the purpose of indicating different geoenvironmental zones from their susceptibility to the processes of superficial dynamics - which implies in their aptitudes and limitations in relation to the use - is also found in a similar way in works like Akgun and Türk (2010), Dai et al. (2001), Manfré et al. (2013) and Fernandes-da-Silva et al. (2010). In these studies, the authors sought to point out sites with greater vulnerabilities to geological and geomorphological processes, based on the physiographic aspects of the terrain and complementing with land use data. Thus, through the multicriteria analysis and weighting and attribution of weights for the different variables, the authors identified geoenvironmental zones with greater or lesser susceptibilities to surface dynamics processes. So in this paper, the weights were assigned according to the characteristics of each physiographic unit, and attributes such as the slope and the potential for geological processes were used (Table V). Since the slope is one of the main triggering agents of surface dynamics processes, and in turn influences the degree of susceptibility of its occurrence, the attribution of weights to 
the units of physiographic compartmentation was established by the evaluation and analysis of the characteristics in each compartment, complemented with the results obtained in the fieldwork. Thus, the physiographic units that had a high susceptibility to processes such as flooding and mass movements, and consequently, low and high slopes, respectively, received higher values of weight (5), whereas units with susceptibility to erosive processes, therefore, low slope values were attributed with lower susceptibility values. Several authors are based on the attribution of weights for susceptibility assessment using the slope relation and occurrence of surface dynamics processes, such as Martini et al. (2006), Regmi et al. (2010), Kayastha et al. (2013) and Feizizadeh and Blaschke (2013). Martini et al. (2006) attributed to slope a high weight of importance because, according to the authors, this variable is directly related to the decrease or increase of the susceptibility to geological processes. So, each declivity class was also established with different weights, which reflect the susceptibility to certain processes (for example, classes with very low slopes were evaluated with high weight due to the occurrence of the flood). Kayastha et al. (2013), following the same precept, attributed a high weight for the slope variable, so that different classes of angles (less than $15^{\circ}, 15$ to $25^{\circ}, 25$ to $35^{\circ}, 35-45^{\circ}$ and slopes over $45^{\circ}$ ) received weights that varied according to the occurrence of mass movements. In turn, the weights of the landuse classes were established according to Lepsch (2002) and Ross (2006) (Table IV).

\section{CONCLUSIONS}

Land-use and physiographic compartmentalization applied to geo-environmental zoning was capable of providing integrated analyses in the assessment of natural characteristics and restrictions, allowing identify different spatial units, extremely important for the environmental planning.
The weighting was fundamental for geoenvironmental zoning, once different conditions (relief, geological, geotechnical, and landuse elements) have differentiated behaviors in relation to geological processes. The ranking of each variable allows combining different zones through the crossing of information, providing the production of a single synthesis map.

As an important result, it was highlighted that the São José dos Campos region has high fragility to geological processes due to its geo-environmental characteristics. In this sense, for geo-environmental units that were identified with high fragility $(C, D$ and $\mathrm{E}$ ), appropriate restoration techniques and the recovery of permanent preservation areas should be conducted to follow the required restrictions under Federal Law 12,651 (Brazil 2012). Thus, slopes, hilltops and floodplains will be safeguarded to inhibit geological processes, such as landslides, creep, debris flow, mass movements, floods and siltation. Furthermore, in the case of large floodplain of the Paraíba do Sul river, mining activities shall be regularized according to zoning laws, once the most vulnerable areas to physical environmental processes need be preserved.

In conclusion, the multicriteria analysis allowed integrating geo-environmental and socioeconomic data, whose outcomes can guide the future installation of new enterprises. The most important advantages of the developed approach over manual mapping are an accessible methodology at relatively low costs, the ease of use of commonly available data with minimal cost, there is no time consuming in the data manipulation, the possibility to explore diverse scenarios, the potential to optimize the land use development, even as the ease of handling the graphic output. Therefore, the products obtained from the remote sensing and GIS has been efficient for territorial planning. Moreover, the methodology used in the present study can be employed in other places, in order to support sustainable decision-making. 


\section{REFERENCES}

AKGUN A AND TÜRK N. Landslide susceptibility mapping for Ayvalik (Western Turkey) and its vicinity by multicriteria decision analysis. 2010. Environ Earth Sci 61: 595-611.

AMARAL AMC, REIS FAGV, GIORDANO LC, CORRÊA CVS AND CHAVES CJ. 2015. Compartimentação fisiográfica pela análise integrada: estudo de caso no município de Casa Branca (SP). Geol USP, Sér Cient 15: 15-28.

ANBAZAGHAN S, SUBRAMANIAN SK AND YANG X. 2011. Geoinformatics in applied geomorphology. Boca Raton: CRC Press, 397 p.

ANDRADE MMN, SZLAFSZTEIN CF, SOUZA-FILHO PWM, ARAÚJO AR AND GOMES MKL. 2010. A socioeconomic and natural vulnerability index for oil spills in an Amazonian harbor: a case study using GIS and remote sensing. J Environ Manag 91: 1972-1980.

ANFUSO G AND DEL POZO JAM. 2009. Assessment of coastal vulnerability through the use of GIS tools in South Sicily (Italy). Environ Manage 43: 533-545.

ASWATHANARAYANA U. 1995. Geoenvironment: an introduction. Rotterdam: Balkema, $270 \mathrm{p}$.

BATHRELLOS GD, GAKI-PAPANASTASSIOU K, SKILODIMOU HD, PAPANASTASSIOU D AND CHOUSIANITIS KG. 2012. Potential suitability for urban planning and industry development using natural hazard maps and geological-geomorphological parameters. Environ Earth Sci 66: 537-548.

BRAZIL. 2012. Lei $\mathrm{n}^{\circ} 12.651$, de 25 de Maio de 2012. Disponível: http://www.jusbrasil.com.br/ legislacao/1032082/lei-12651-12. Acessado em 9 de janeiro de 2015.

CARDOSO D, RIEDEL PS, VEDOVELLO R, BROLLO MJ AND TOMINAGA LK. 2009. Compartimentação fisiográfica do município de Peruíbe, litoral de São Paulo - uma abordagem metodológica como subsídio à avaliação geotécnica de terrenos. Pesquisa em Geociências 36: 251262.

CETESB - COMPANHIA AMBIENTAL DO ESTADO DE SÃO PAULO. 2002. Lei Estadual n ${ }^{\circ} 11.262$, de 08 de Novembro de 2002. Disponível: http://www.cetesb.sp.gov. br/licenciamento/legislacao/estadual/leis/2002_Lei_ Est_11262.pdf. Acessado em 2 de abril de 2015.

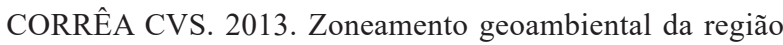
compreendida pelas folhas topográficas São José dos Campos e Jacareí-SP. Tese de Doutorado, UNESP (Universidade Estadual Paulista "Júlio de Mesquita Filho").

CORRÊA CVS, REIS, FAGV, GIORDANO LC AND BRITO HD. 2014. Emprego de técnicas de sensoriamento remoto na compartimentação fisiográfica da região abrangida pelas folhas topográficas São José dos Campos e Jacareí (SP). Rev Bras Carto 66: 1281-1294.

DA-SILVA APF AND RODRIGUES-CARVALHO JA. 2006. Engineering geological mapping for the urban planning of Almada County, Portugal. In: Culshaw MG, Reeves HJ, Jefferson I and Spink TW (Eds), Engineering geology of tomorrow's cities. London: Geological Society, $165 \mathrm{p}$.

DAI FC, LEE CF AND ZHANG XH. 2001. GIS-based geoenvironmental evaluation for urban land-use planning: a case study. Eng Geol 61: 257-271.

DEPARTAMENTO DO AMBIENTE DO ESTADO DE SÃO PAULO. 1999. Resolução SMA no 28, de 22 de Setembro de 1999. Disponível: http://licenciamento.cetesb.sp.gov. br/legislacao/estadual/resolucoes/1999_Res_SMA_28. pdf. Acessado em 28 de março de 2015.

DINIZ TD, ZAINE JE AND RODRIGUES FH. 2016. Compartimentação fisiográfica aplicada ao mapeamento em detalhamento progressivo do núcleo urbano central de Ilhabela-SP. Geol USP, Sér Cient 16(3): 57-70.

ELSHEIKH RFA, SHARIFF ARBM AND PATEL N. 2015. Mango suitability evaluation based on GIS, multi criteria weights and sensitivity analysis. International Journal of Advanced Computer Research 5(18): 25-34.

FEIZIZADEH B AND BLASCHKE T. 2013. GIS-Multicriteria Decision Analysis for landslide susceptibility mapping: comparing three methods for the Urmia lake basin, Iran. Nat Hazards 65: 2105-2128.

FERNÁNDEZ DS AND LUTZ MA. 2010. Urban flood hazard zoning in Tucumán Province, Argentina, using GIS and multicriteria decision analysis. Eng Geol 111: 90-98.

FERNANDES-DA-SILVA PC AND CRIPPS JC. 2011. Geoenvironmental Terrain Assessments Based on Remote Sensing Tools: A Review of Applications to Hazard Mapping and Control. Environmental Management in Practice 5: 85-118.

FERNANDES-DA-SILVA PC, VEDOVELLO R, FERREIRA CJ, CRIPPS JC, BROLLO MJ AND FERNANDES AJ. 2010. Geo-environmental mapping using physiographic analysis: constraints on the evaluation of land instability and groundwater pollution hazards in the Metropolitan District of Campinas, Brazil. Environ Earth Sci 61: 16571675.

FLORENZANO TG. 2008. Geomorfologia: conceitos e tecnologias atuais. São Paulo: Oficina de Textos, 104 p.

FLORENZANO TG AND CSORDAS SM. 1993. Mapa geomorfológico da Região do Médio Vale do Paraíba e Litoral Norte do Estado de São Paulo. INPE, São José dos Campos, Brasil. Escala: 1:250,000.

FONTES SB AND PEJON OJ. 2008. Proposal of a geoenvironmental zoning method based on Ottobasin compartmentalization. Bull Eng Geol Environ 67: 555563. 
IFEANYI CE, ADOH EM AND ALABI MO. 2010. Evaluation of ecoenvironmental vulnerability profiles in Efon-Alaye using remote sensing and GIS techniques. J Geogr Reg Plan 3: 8-16.

IBGE - INSTITUTO BRASILEIRO DE GEOGRAFIA E ESTATÍSTICA. 1973. Folha de São José dos Campos. IBGE, São Paulo, Brasil. SF-23-Y-D-II-1. Escala: $1: 50,000$.

IBGE - INSTITUTO BRASILEIRO DE GEOGRAFIA E ESTATÍSTICA. 1974. Folha de Jacareí. IBGE, São Paulo, Brasil. SF-23-Y-D-II-3. Escala: 1:50,000.

IBGE - INSTITUTO BRASILEIRO DE GEOGRAFIA E ESTATÍSTICA. 2006. Manual Técnico de Uso da Terra. IBGE, Rio de Janeiro, Brasil.

INPE - INSTITUTO NACIONAL DE PESQUISAS ESPACIAIS. 2008. Topodata: Banco de dados Geomorfométricos do Brasil. Disponível: http://www.dsr. inpe.br/topodata/index.php. Acessado em 12 de janeiro de 2012.

INPE - INSTITUTO NACIONAL DE PESQUISAS ESPACIAIS. 2011. Software Spring 5.1.8. Brasília, Brazil. Available: http://www.spring.org.br/. Accessed: 30 January 2012.

IPT - INSTITUTO DE PESQUISAS TECNOLÓGICAS DO ESTADO DE SÃO PAULO. 1978. Mapa Geológico Folha São José dos Campos. IPT, São Paulo, Brasil. SF23-Y-D-II. Escala: 1:100,000.

IPT - INSTITUTO DE PESQUISAS TECNOLÓGICAS DO ESTADO DE SÃO PAULO. 1981. Mapa Geomorfológico do Estado de São Paulo. IPT, São Paulo, Brasil. Escala: $1: 100,000$.

JIMENEZ-RUEDA JR, LANDIM PMB AND MATTOS JT. 1995. Gerenciamento Geoambiental. In: Tuk-Tornisielo SM, Gobbi N, Foresti C and Lima ST (Orgs), Análise Ambiental: estratégias e ações. São Paulo: T.A. CEA/ UNESP, p. 327-329.

KAYASTHA P, DHITAL MR AND DE-SMEDT F. 2013. Application of the analytical hierarchy process (AHP) for landslide susceptibility mapping: A case study from the Tinau watershed, west Nepal. Comput Geosci 52: 398408.

KONG C, LAN H, YANG G AND XU K. 2016. Geoenvironmental suitability assessment for agricultural land in the rural-urban fringe using BPNN and GIS: a case study of Hangzhou. Environ Earth Sci 75: 1136-1150.

KOTTEK M, GRIESER J, BECK C, RUDOLF B AND RUBEL F. 2006. World map of the Köppen-Geiger climate classification updated. Meteorologische Zeitschrift 15: 259-263.

LEPSCH IP. 2002. Conservação dos solos. São Paulo: Caderno de textos, $316 \mathrm{p}$.

LIMA KC, CUNHA CML AND PEREZ-FILHO A. 2013. Dificuldades e possibilidades da Cartografia
Geomorfológica no semiárido brasileiro. Rev Bras Carto 65: 1063-1073.

MANFRÉ LA, DA-SILVAAM, URBAN RC AND RODGERS J. 2013. Environmental fragility evaluation and guidelines for environmental zoning: a study case on Ibiuna (the Southeastern Brazilian region). Environ Earth Sci 69: 947957.

MARTINI LCP, UBERTI AAA, SCHEIBE LF, COMIN JJ AND DE-OLIVEIRA MAT. 2006. Avaliação da suscetibilidade a processos erosivos e movimentos de massa: decisão multicriterial suportada em sistemas de informações geográficas. Geol USP, Sér Cient 5(2): 41-52.

OLIVEIRA TA. 2004. Compartimentação fisiográfica aplicada à avaliação de terrenos - subsídio ao planejamento territorial do município de Cananéia-SP. Tese de Doutorado, (Universidade Estadual Paulista "Júlio de Mesquita Filho").

PANDEY A, DABRAL PP, CHOWDARY VM AND YADAV NK. 2008. Landslide hazard zonation using remote sensing and GIS: a case study of Dikrong River Basin, Arunachal Pradesh, India. Environ Geol 54: 1517-1529.

PILACHEVSKY T, REIS FAGV, GIORDANO L, MASCARO SA AND MACEDO JGC. 2015. Compartimentação fisiográfica aplicada ao planejamento ambiental territorial: estudo de caso no munícipio de São João da Boa Vista (SP). Rev Bras Carto 67: 83-96.

POUREBRAHIM S, HADIPOUR M AND BIN MOKHTAR M. 2011. Integration of spatial suitability analysis for land use planning in coastal areas: case of Kuala Langat District, Selangor, Malaysia. Landsc Urban Plan 101: 84-97.

RAMPANELLI AM, SAAD AR, ARAÚJO NETO E, CASADO FC AND ETCHEBEHERE MLC. 2011. Recursos naturais da Bacia Sedimentar de Taubaté como fator de desenvolvimento socioeconômico: um estudo aplicado aos municípios de Taubaté e Tremembé, Estado de São Paulo. Geociências 30: 327-343.

REGMI NR, GIARDINO JR AND VITEK JD. 2010. Assessing susceptibility to landslides: Using models to understand observed changes in slopes. Geomorphology 122: 25-38.

ROSS J. 2006. Ecogeografia do Brasil: subsídios para o planejamento ambiental. São Paulo: Oficina de Textos.

ROSS JLS AND MOROZ IC. 1997. Mapa geomorfológico do Estado de São Paulo. USP/IPT/FAPESP, São Paulo, Brasil. Escala: 1:500,000.

SILVA PCF, VEDOVELLO R, FERREIRA CJ, CRIPPS JC, BROLLO MJ AND FERNANDES AJ. 2010. Geoenvironmental mapping using physiographic analysis: constraints on the evaluation of land instability and groundwater pollution hazards in the Metropolitan District of Campinas, Brazil. Environ Earth Sci 61: 1657-1675.

SMITS PC, DELLEPIANE SG AND SCHOWENGERDT RA. 1999. Quality assessment of image classification algorithms for land-cover mapping: a review and a 
proposal for a cost based approach. International Journal of Remote Sensing 20: 1461-1486.

SOARES PC AND FIORI AP. 1976. Lógica e sistemática na análise e interpretação de fotografias aéreas em geologia. Not Geomorfológica 32: 71-104.

SZLAFSZTEIN C AND STERR H. 2007. A GIS-based vulnerability assessment of coastal natural hazards, state of Pará, Brazil. J Coast Res 11: 53-66.

TINÓS TM, FERREIRA MV, ZAINE JE AND RIEDEL PS. 2014. Técnicas de visualização de Modelos Digitais de Elevação para o reconhecimento de elementos de análise do relevo. Revista Geociências, UNESP 33(2): 202-215.

TUDES S AND YIGITER ND. 2010. Preparation of land use planning model using GIS based on AHP: case study Adana-Turkey. Bull Eng Geol Environ 69: 235-245.

VEDOVELLO R. 2000. Zoneamentos Geotécnicos Aplicados à Gestão Ambiental, a partir de Unidades Básicas de Compartimentação - UBCs. Tese de Doutorado, UNESP
(Universidade Estadual Paulista "Júlio de Mesquita Filho").

VEDOVELLO R AND MATTOS JT. 1993. Zoneamento

Geotécnico por Sensoriamento Remoto para estudos de Planejamento do Meio Físico: aplicação em expansão urbana. In: Anais do Simpósio Brasileiro de Sensoriamento Remoto. INPE, Curitiba, 7, 155-162.

VEDOVELLO R AND MATTOS JT. 1998. A Utilização de Unidades Básicas de Compartimentação (UBCs) como base para a definição de unidades geotécnicas: Uma abordagem a partir de sensoriamento remoto. In: Anais do Simpósio Brasileiro de Cartografia Geotécnica. ABGE, Florianópolis.

ZAINE JE. 2011. Método de Fotogeologia aplicado a estudos geológico-geotécnicos: ensaio em Poços de Caldas, MG. Tese de Doutorado, UNESP - (Universidade Estadual Paulista "Júlio de Mesquita Filho"). 